\title{
Plasticulture as a means of vine management method in cucumber (Cucumis sativus I.) production a mini review
}

\begin{abstract}
Cucumber (Cucumis sativus L.) is an annual, crawling fruit vegetable grown in the temperate and sub-tropical zones of the world. Cucumber is a very good source of vitamins A, C, K, B6, potassium and also provides dietary fiber, pantothenic acid, magnesium, phosphorus, copper and manganese. In spite of the good attributes, cucumber production is still mainly done by very few farmers in Nigeria especially in urban and peri-urban areas due to lack of technical know-how on the cultural practices to produce marketable fruits with good quality. Also, production is low due to poor vine management. Inappropriate vine management has been noted to result in vines trailing on ground which promotes overcrowding, disease infestation and poor fruits quality. Premise to above, modern technology of Plasticulture is therefore advocate for better yield production. Plasticulture defined as the use of plastics as a means of mulching materials in crop/vegetable production. The use of Plasticulture in the production of crops helps to mitigate the extreme fluctuations in weather, especially temperature, rainfall and wind. Agriculture is known for its multi-functionalities of providing employment, livelihood, food, nutritional and ecological securities. So the adoption of modern technology to overcome natural constraints to successful agriculture with limited water resources is essential in this context, mulching may prove beneficial for crop growth because of complex change in soil environment through modifying soil temperature, reduction in evaporation, weed competition, soil compaction and erosion. Plastic mulch is a product used, in a similar fashion to mulch, to suppress weeds and conserve water in crop production.
\end{abstract}

Keywords: plasticulture, mulch, vine management, microclimate, trailing, food, nutritional, ecological securities, crop growth, soil temperature, livelihood, oldest vegetables
Volume 2 Issue 3 - 2018

\author{
Ajibola Olufemi Victor, Amujoyegbe Bamidele \\ Julius \\ Department of Crop Production and Protection, Obafemi \\ Awolowo University, Nigeria
}

Correspondence: Ajibola Olufemi Victor, Department of Crop Production and Protection, Obafemi Awolowo University, Nigeria, Tel +2348032132944, Email vicajibolafirst@gmail.com

Received: October 30, 2017| Published: June 25, 2018

\section{Introduction}

Cucumber (Cucumis sativus L.) is an important fruit vegetable crop grown in the temperate and sub-tropical zones of the world. ${ }^{1,2}$ Historically, it is one of the oldest vegetables cultivated by man about 5,000 years ago. ${ }^{3}$ Written evidence indicates that cucumber originated in India, which spread westward and became popular throughout the Egyptian and the Greek-Roman eras. Cucumber is an annual crop and a climbing herb. It is a thermophile plant that requires a stable warm temperature for good yield. ${ }^{4}$ In favorable conditions, its growth development duration can last 12-13 months. The cucumber root system develops weakly. Root length can be $10-25 \mathrm{~cm}$ in sandy loam soil. Cucumber root system makes up $1.5 \%$ of the total biomass. Secondary roots distribute on the surface covering an area of about $60-90 \mathrm{~cm}$ wide. The leaves are alternate, simple and triangular-ovate. Leaf-blades are 3-7 lobed and deeply cordate at base. The stems of the cucumber produce vines; are 4-5 angled and sparingly branched. The length of the main stem may be 2-3 m. Cucumber flowers are axillary and unisexual and occasionally hermaphrodite. The fruit is composed mostly of water; more than $96 \%$ of edible unpeeled fruit is water. ${ }^{5}$ Cucumber is a very good source of vitamins A, C, K, B6, potassium and also provides dietary fiber, pantothenic acid, magnesium, phosphorus, copper and manganese. ${ }^{6}$ Cucumber production in most part of Nigeria is fast becoming popular, ${ }^{7}$ probably because of its high nutritional and medicinal values, as well as being a useful component ingredient in pharmaceutical. ${ }^{8}$ In spite of the good attributes, cucumber production is still mainly done by very few farmers in Nigeria especially in urban and peri-urban areas due to lack of technical know-how on the cultural practices ${ }^{7}$ to produce marketable fruits with good quality. Also, production is low due to poor vine and fertility management. ${ }^{9}$ Inappropriate vine management has been noted by ${ }^{9}$ to result in vines trailing on ground which promotes overcrowding, disease infestation and poor fruits quality ${ }^{10}$ reported positive effect of different vine management method on leaf, branch numbers and vine length which could be attributed to the proper exposure of leafs to sunlight. Premise to the above, the application of Plasticulture as a means of vine management is therefore encourage.

Plasticulture is a crop production technique that has been used by vegetable growers for many years, it is involves placement of inorganic materials on the soil surface and it has many advantages which include: to prevent loss of soil moisture, to control weeds by shading them and diseases by preventing soil contact with the plant foliage, to control soil temperature, either by keeping it cool or keeping it warm, to maintain soil fertility due to erosion and retain soil organic matter content. ${ }^{11}$ Cucumber requires a stable warm temperature for good yield. ${ }^{4}$ According to, ${ }^{12}$ the use of black plastic mulch on cucumber plots produced higher yields and compensated additional costs of production input in Germany. Also, ${ }^{13}$ reported that plastic mulch on cucumber increased production by 4.6 t/ha in Pueto Rico. Some mulch materials such as the reflective mulches are efficient in repelling insects ${ }^{14}$ in rain forest Nigeria, growing of cucumber is rarely practiced because of its special ecological requirement with extreme temperatures, heavy rainfall and high humidity. All these hinder effective production practices of most crops in the area. However, for a cucumber, the use of mulching is considered to help moderate the 
ecological problems. ${ }^{11}$ The commonly used mulching materials are polyethylene, straw, wood shavings and other plant debris. However, response of crops to mulch depends on the crop species, prevailing climate, production system and type of mulch. ${ }^{12-14}$ Mulches primarily affect the field microclimate by modifying the radiation budget of the surface and suppressing soil water evaporation. These microclimate factors strongly affect the soil temperature and moisture in the root zone, which in turn may influence plant growth and productivity. ${ }^{15}$ Mulching can improve early and total yield ${ }^{16}$ and fruit quality. ${ }^{17}$ In addition, mulches increase the efficiency of water uptake and fertilizer use $^{18}$ and reduce weed competition. ${ }^{15}$

It is has been reported that mulching of cucumber in the rain forest zone of Nigeria should fall between 3 weeks after planting to get reasonable yield. ${ }^{11}$ White plastic mulch absorbs little solar radiation but transmits $85 \%$ to $95 \%$ of incoming solar radiation. The under surface of clear plastic mulch usually is covered with condensed water droplets and this water is transparent to incoming shortwave radiation but is opaque to outgoing long wave infrared radiation; so much of the heat is retained by clear plastic mulch. ${ }^{19}$ Thus, daytime soil temperatures are generally 8 to $14^{\circ} \mathrm{F}$ higher at a 2-inch depth and 6 to $9^{\circ} \mathrm{F}$ higher at a 4-inch depth compared to those of bare soil. ${ }^{20}$ White plastic mulch also used in some areas due to its increased soil warming characteristics. Research has shown that white or aluminum reflective mulch also repels aphids which spread some virus diseases in vine crops such as cucumber. White mulch provides an even warmer soil environment than black plastic mulch, but requires the use of another technique to control weeds (herbicide, soil fumigant or solarization). White, white on-black reflective mulches can result in a slight increase or even a slight decrease in soil temperature compared to bare soil, tending to minimize changes in soil temperature, because they reflect back into the plant canopy most of the incoming solar radiation. Black plastic mulch is the predominate color used in plant production is an opaque blackbody absorber and radiator. Black mulch absorbs most Ultra Violet, visible, and infrared wavelengths of incoming solar radiation and re-radiates absorbed energy in the form of thermal radiation or long-wavelength infrared radiation. Soil temperatures under black plastic mulch during the daytime are generally $5^{\circ} \mathrm{F}$ higher at a 2 -inch depth and $3^{\circ} \mathrm{F}$ higher at a 4-inch depth compared to those that of bare soil. ${ }^{20}$ The efficiency with which black mulch increases soil temperature can be improved by optimizing the condition for transferring heat from the mulch to the soil. ${ }^{21}$

Among different mulching techniques plastic film mulching increases soil surface temperature by influencing the heat balance and thus increased the soil temperature and it also positively influenced the crop emergence ${ }^{21}$ Soil water content. The black polyethylene mulch maintained high soil water contents compared to the control (no mulch) and the bare soil treatments. ${ }^{22}$ Improvement of the water use efficiency by better utilization of soil water appears to be the best way to increase grain yield in the semiarid areas. ${ }^{23}$ The main ways of increasing the water use efficiency include reducing soil water evaporation, and exploiting deep soil water so as to support shoot biomass accumulation and optimize the dry matter allocation by selectively increasing the reproduction. ${ }^{24}$ The plastic film mulch was promoted root growth and that more roots were distributed in midand deep-soil, so that the plant can uptake water from the deep soil and increase the grain yield. ${ }^{25}$ Black plastic mulch is most commonly used in agriculture. It was reported that there was $15 \%$ moisture conservation in crops due to black polyethylene mulching and $20 \%$ saving in a various variety of vegetable. ${ }^{26}$ Black plastic mulch was most effective in weed control in tomato and cucumber and resulted in more crop growth and higher fruit yield when it was compared with organic mulches like cassava peel, giant star grass and guinea grass straw. ${ }^{27}$ Results obtained by demonstrated that polyethylene mulch had a significant effect on weed density. Research has concluded that Mulching made effective change in increasing horticultural crop production in water scarcity regions. Plastic mulching using black polyethylene is recommended for vegetables and has the advantages of attaining earliness in production, better fruit quality and greater total yield.

\section{Conclusion}

Plasticulture is a technique that has been in existence with the positive effect for fruits-vegetables growers. It has been noted that under Plasticulture, soil properties and nutrient availability is maintained. The plant physiology, morphology and yield are also increased by the effect of plastic mulching due to improve of soil microclimate of the soil. However, the cost of plastic, removal and disposal of plastic materials are some constrain observed by the farmers. Therefore, it is advised to make use of biodegradable plastic mulches for sustaining the productivity and controlling environmental pollution.

\section{Acknowledgements}

None.

\section{Conflict of interest}

The author declares there is no conflict of interest.

\section{References}

1. Adams P, Graves CJ, Winsor GW. Some Responses of Cucumbers, Grown in Beds of Peats to N, K and Mg. J Hort Sci. 1992;67:877-884.

2. Thoa DK. Cucumber seed multiplication and characterisation. AVRDC/ ARC Training Thailand. 1998.

3. Wehner TC, Guner N. Growth stage, flowering pattern, yield and harvest date prediction of four types of cucumber tested at 10 planting dates. Proceeding xxvi IHC. 2004;1-7.

4. Cobeil G, Gosselin A. Influence of pruming and season on productivity of cucumber plants grown in a sequence cropping system scientia. Horticultural. 1990;41(3):189-200.

5. van Luijk MN. Cucumis sativus L. Wageningen, Netherlands. 2004.

6. Vimala P, Ting CC, Salbiah H. Biomass production and nutrient yields of four green manures and their effects on the yield of cucumber. Journal of Tropical Agriculture and Food Science. 1999;27:47-55.

7. Nweke IA, Orji EC, Ijearu SI. The effect of Staking and Plant Spacing on the growth and yield of Cucumber (Cucumis Sativus L.). IOSR Journal of Environmental Science, Toxicology and Food Technology (IOSRJESTFT). 2013;3(4):26-31.

8. Kumar D, Kumar S, Singh J, et al. Free Radical scavenging and Analgesic Activities of Cucumis sativus L. Fruit Extract. J Young Pharm. 2010;2(4):365-368.

9. Ayotamuno JM, Zoufa K, Ofori SA, et al. Response of Maize and Cucumber Intercrop to Soil Moisture Control Through Irrigation and Mulching During the Dry Season in Nigeria. Afri J Biotechnol. $2007 ; 6: 509$ 
10. Ajibola OV, Amujoyegbe BJ. Vine management and organominera fertilizer effects on morphology and fruit yield of cucumber (Cucumis sativus L.). Int J Agric Sc \& Vet Med. 2017;5(1):17-23.

11. Ibeawuchi II, Opara RI, Oyibo PO, et al. Effect of time of mulch application on the growth and yield of cucumber (Cucumis sativus) in Owerri, southeastern Nigeria. Life Science Journal. 2007;5(1):68-71.

12. Struzina AJ, Kromer KH. Effect and costs of mulching. Hart Bulletin. 1989;59:32.

13. Goyal MR, Allison WF. Summer drip virigation requirements for cucumber. Journal of Agriculture the University of Pucto Rico. $1983 ; 6: 229$.

14. AVRDC (Asian Vegetable Research Development Centre). Vegetable Production Training Manual. AVRDC Shanhua Talnau, Taiwan. $1990 ; 182$.

15. Aguyoh J, Taber HG, Lawson V. Maturity of fresh market sweet corn with direct seeded plants, transplants, clear plastic mulch and row cover combinations. Horticulture Technology. 1999;9(3):420-425.

16. Bhella HS, Kwolek WF. The effects of trickle irrigation and plastic mulch on 'Zucchini'. Horticultural Science. 1998;19(3):410-411.

17. Perry KB, Sanders DC. Tomato yield as influenced by plant rotation systems. Horticultural Science. 1986; 21(2): 238-239.

18. Wien HC, Minotti PL, Grubinger VP. Polyethylene mulch stimulates early root growth and nutrient uptake of transplanted tomatoes. Journal of American Society of Horticultural Science. 1993;118(2):207-211.

19. Coleman E. The New Organic Grower: A Master's Manual of Tools and Techniques for the Home and Market Gardener. 2nd edition. Chelsea Green Publishing, Lebanon. 1995.
20. Lamont WJ. The use of different colored mulches for yield and earliness. Proceedings of the New England Vegetable and Berry Growers Conference and Trade Show, Sturbridge. 1999;299-302.

21. Aniekwe NL, Okereke OU, Anikwe MAN. Modulating Effect of Black Plastic Mulch on the Environment, Growth and Yield of Cassava in a Derived Savanna Belt of Nigeria. Tropicultura. 2004;22(4):185-190.

22. Lalitha M, Kasthuri Thilagam, Balakrishnan N, et al. Effect of plastic mulch on soil properties and crop growth-a Review. Sci Agric Sin. 2001;34(2):330-333.

23. Li Fengmin, Guo Anhong, Luo Mei, et al. Effect of water supply from deep soil on dry matter production of winter wheat. Chin J Appl Ecol. 1997;8(6):575-579.

24. Kwabiah AB. Growth and yield of sweet corn (Zea mays L.) cultivars in response to planting date and plastic mulch in a short-season environment. Scientia Hort. 2004;102(2):147-166.

25. NCPAH. 1991

26. Asiegbu JE. Response of tomato and eggplant to mulching and nitrogen fertilization under tropical conditions. Scientia Horticulturae. 1991;46(12):33-41.

27. Hatami S, Nourjou A, Henareh M, et al. Comparison effects of different methods of black plastic mulching and planting patterns on weed control, water use efficiency and yield in tomato crops. International Journal of Agricultural Sciences. 2012;2(10):928-934. 